\title{
O CRIME NO PERIODO PRODRÔMICO DA ESQUIZOFRENIA
}

\author{
DARCY DE MENDONÇA UCHOA * \\ LUIZ PINTO DE TOLEDO **
}

\section{CONSIDERAÇŐES PRELIMINARES}

A psiquiatria científica, à medida que progride no conhecimento da personalidade integral, traz subsídios cada vez mais preciosos para a elucidação de situações complexas criadas pelo infrator da ordem social. Orientada pelas modernas escolas de psicologia dinâmica, aprofunda-se cada vez mais a psicopatologia num esfôrço grande por descobrir os sinais mais precoces e mais sutis que possam já traduzir uma mente enferma, numa fase em que aparentemente não há ainda fenomenologia mórbida. A psicopatologia, penetrando cada vez mais no campo da ciência do crime, tende a elucidar alguns dos aspectos mais misteriosos e inquietantes do ato criminoso. Com efeito, muitos são os crimes que tanto chocam a opinião pública e a própria justiça por falta de qualquer fundamento de ordem racional, sem qualquer motivo de ordem aparente, por mínimo que seja, que o justifique, obrigando cientistas e legisladores a formulares meros juizos de yalor a respeito de seus autores, quer sob forma de uma maldade hereditária ou imanente, quer sob forma de conceitos vagos e indefinidos de degeneração mental. É sabido como a aceitação da doutrina do livre arbítrio, base ainda de quasi todos os códigos penais, tanto se inspirou na primeira premissa, o indivíduo tendo fốrças para optar pelo bem ou pelo mal, e como a escola positiva, com Lombroso e seus arautos, tanto se inspirou na segunda. Quaisquer que tenham sido as vantagens desta última orientação, mostrou-se ela insatisfatória, talvez por demasiado rígida em seus conceitos, tendentes de certo modo ao fatalismo biológico, o que explica, a nosso vêr, a formação de tantas subescolas e pontos de vista vários, mesmo entre discípulos e admiradores de Lombroso. Teve-se que apelar, em grande parte, para conceitos de ordem social, para fundamentar o problema da responsabilidade. Em vez duma responsabilidade apoiada em conceitos filosóficos de moral, falou-se numa responsabilidade social, apelando-se, dentre outros fatores, para a "qualidade dos motivos" (Ferri). Tudo isso demonstra que os pro-

* Psiquiatra do Hospital de Juquerí.

** Psiquiatra do Manicômio Judiciário do Estado de S. Paulo. 
gressos trazidos pela antropologia científica, incontestes embora, mostraram-se todavia insatisfatórios. $O$ moderno psiquiatra forense, não raro, sente-se perplexo diante dos problemas delicados e sutis criados por certa classe de criminosos que pairam em toda uma zona intermediária entre uma personalidade bem ajustada psicosocialmente e outra com evidentes distúrbios mentais. Cada vez mais tende êle a se orientar no sentido interpretativo-psicológico, buscando causas, motivos de delinquência, traços caracterológicos e temperamentais que eventualmente facilitam ou dificultam a ação delituosa, constelações favoráveis ou desfavoráveis, complexos que por vias indiretas e tortuosas se derivam muitas vezes em ações antissociais. Nesse esfôrço sente-se que, de um ponto de vista psicológico-social, o perito tende a completar os dados preciosos já fornecidos à criminologia pela ciência antropológica. Do ponto de vista mais particular de nosso estudo, impressionou-nos o fato da existência, no Manicômio Judiciário do Estado, de muitos indivíduos que perpretaram graves crimes de sangue, não raro com excessiva violência, sem motivo de ordem racional ou com motivação demasiado futil, os quais representaram com frequência atos contrastantes com sua personalidade anterior. Com efeito, até o momento da ação criminosa, não tinham exteriorizado qualquer anormalidade mental, e, pouco depois dela, apresentaram francos quadros esquizofrênicos, alguns deles com muita gravidade. O estudo meticuloso desses casos fez-nos concluir já serem êles portadores de morbidez psíquica na época do crime, a modo de um estado prodrómico da psicose, o ato criminal representando assim o sinal de alarme da grave enfermidade que posteriormente iria irromper. Aliás, problemas tais já têm sido estudados por vários autores e, ao publicarmos nosso estudo, o fazemos pela extraordinária importância do assunto não só do ponto de vista humano e social, como tambem pelas consequências no campo da criminologia e da psicopatologia forense. E solução bem diversa a internação de tais criminosos, enfermos mentais sem dúvida, em hospitais psiquiátricos para serem convenientemente estudados e tratados, que sua condenação e segregação da sociedade, com o sêlo infamante inevitável, em cadeias e penitenciárias, a maioria delas ainda com intensões punitivas manifestas. Daí o nosso estudo, daí a idéia da publicação dos nossos casos, que apresentam uma contribuição pequena, desvaliosa é certo, mas real e sincera para cada vez melhor elucidação dêste tão importante problema de psiquiatria forense. 
DO CONCEITO DE DEMENCIA PRECOCE DE KRAEPELIN AO DAS ESQUIZOFRENIAS DE BLEULER. ESQUIZOFRENIA LATENTE. PERSONALIDADE ESQUIZOIDE. IMPORTANCIA DO DIAGNOSTICO PRECOCE DA ESQUIZOFRENIA

Por mais radical que seja a revisão crítica da obra de Kraepelin ${ }^{1}$, é inegável que o grande mestre de Munich muito concorreu para ordenar e sistematizar os conhecimentos psiquiátricos, em fins do século passado, lançando, sem dúvida, os marcos iniciais de uma psiquiatria científica. Sua larga experiência clínica e ampla visão dos problemas psicopatológicos posstbilitaram melhor reagrupamento dos quadros nosográficos, não raro unificando síndromes - por outros autores que o precederam consideradas unidades clínicas independentes - quando descobria, em essência, a mesma infraestrutura fundamental e o mesmo tipo de evolução. Assim é que divisou na "idiotia adquirida de Esquirol", "estupidez ou demência juvenil de Morel", "catatonia e hebefrenia de Kahlbaum-Hecker", traços fundamentais que justificaram sua fusão em uma só entidade clínica por êle denominada demência precoce - enfermidade grave caracterizada pelo aparecimento precoce, na puberdade ou mesmo antes, de sintomatologia vária, indicando processo destrutivo-orgânico da personalidade, evoluindo para a demência. Por mais justo que fosse tal conceito, casos com tal denominação rubricados surgiram que, posto conservando a fenomenologia clínica da enfermidade, tiveram seu início em idades mais avançadas e não evoluiram sistematicamente para a demência. Muitos dêles remitiam e outros evoluiam para estados terminais com caracteres de pronunciado embotamento afetivo antes que de demência propriamente dita. Foi o estudo acurado de tais pacientes que levou Bleuler, em $1911^{2}$, a substituir a expressão demência precoce pela de esquizofrenias (têrmo de Wolff) pois, como acertadamente escreveu o psiquiatra de Zurich, "como a doença não evolue necessàriamente para a demência e nem sempre é precoce, isto é, não aparece na puberdade sòmente ou pouco depois, cabe melhor o nome de esquizofrenia". "Esta doença pode estacionar em qualquer dos estádios, e muitos dos sintomas podem em grande parte ou inteiramente regredir; porém, quando ela prossegue, conduz a um embotamento de determinado carater " $"$ ". Destacou êle sintomas fundamentais ou primários e secundários ou acessórios. Entre os primeiros: distúrbios da associação, da afetividade, ambivalência, autismo; entre os segun-

1. Kraepelin, E. - Dementia praecox and Paraphrenia. $8 .^{a}$ edição. Tradução ingleza, 1919.

2. Bleuler, E. - Dementia praecox oder Gruppe der Schizophrenien. Handbuch der Psychiatrie de G. Aschaffenburg, Leipzig, 1911.

3. Bleuler, E. - Lehrbuch der Psychiatrie, Leipzig, 1911. 
dos: distúrbios senso-perceptivos, idéias delirantes, fenômenos motores, estados confusionais, perturbações da memória, etc.

Procurando descobrir os fatores causais, observou Bleuler, mercê de cuidadosas anamneses que, em muitos casos, bem antes de se instalarem os sintomas psicóticos, já apresentavam os pacientes determinadas anomalias de carater e de comportamento. Muitas vezes tais distúrbios da personalidade não evoluiam para a psicose franca e, em outras ocasiões, mostravam-se constantes em pacientes em remissão.

Concebeu assim a "esquizofrenia latente". Os estudos de Krestschmer ${ }^{4}$ vieram, sem dúvida, melhor precisar e aprofundar os fatores heredoconstitucionais (côrpo, temperamento e carater) em relação com os dois grandes grupos de psicoses "endógenas - a esquizofrenia e a psicose maníaco depressiva - pesquisas posteriormente completadas pelos estudos de Minkowski sôbre o temperamento gliscróide e suas relações com a personalidade explosiva (constituição epiléptica). Baseando-se em dados recolhidos sôbre os antecedentes pessoais e hereditários de seus enfêrmos, concebeu Kretschmer dois grandes grupos de caracteres anormais - os ciclóides e os esquizóides - e, dentro do campo dos indivíduos normais, os temperamentos ciclotímicos e esquizotimicos. Quanto aos primeiros, suas reações variariam entre a alegria e tristeza, o que denominou "proporção diatésica ou coeficiente de humor" do ciclóide, enquanto os esquizóides oscilariam entre a anestesia e a hiperestesia afetivas - proporção psicoestésica de Kretschmer - ou melhor, encerraria a personalidade esquizóide traços anestésicos e hiperestésicos simultaneamente, com predominância de um dos polos. $O$ comportamento do indivíduo em relação à ambiência se mostrou antitético nos dois casos. Oposição, rotura mais ou menos completa com o meio, perda do contacto afetivo (Bleuler) ou perda do contacto vital com a realidade (Minskowski) ${ }^{5}$ caracterizando os esquizof rênicos e, menos intensamente, os caracteres esquizóides, e, pelo contrário, o contacto com o ambiente, tendência a fundir-se com a realidade imediata, no grupo dos ciclóides levando aus estados maníaco-depressivos. Como é sabido, o conceito de personalidade esquizóide, base fenotípica das reações esquizofrênicas, engloba as pessoas comumente designadas de extravagantes, lunáticas, incompreensíveis, raras, em virtude das anomalias caracterológicas que the são peculiares. Taciturno em certas ocasiões, caprichoso em outras, despótico e fanático, o esquizóide se adapta dificilmente ao meio social, vivendo a seu modo, com o núcleo de sua perso-

4. Kretschmer, E. - La structure du corps et le caractère. Tradução franceza por Jankélévitch. Ed. Payot, Paris, 1930.

Kretschmer, E. - Medizinische Psychologie. Leipzig, 1939.

5. Minkowski, E. - La schizophrenie. Ed. Payot, Paris, 1927.

Minkowski, E. - La genèse de la notion de schizophrenie et ses caracteres essentiels. L'evolution Psychiatrique. Ed. Payot, Paris, 1927. 
nalidade fechado aos demais, que o não conseguem compreender de modo lógico e empático. Volúvel nas suas idéias e afetos, que só mui dificilmente sofrem a ação das influências externas, age por vezes brusca e violentamente em contraposição ao comportamento passivo, indiferente, como alheiado ao meio, que tanto caracteriza suas atitudes de introversão e autismo. Kretschmer diz possuirem os esquizóides uma superficie e uma profundidade. "São de uma brutalidade decisiva ou mal humorados, com uma ironia penetrante ou selvagem, retirando-se sem ruido: eis a superfície. Mas a superfície nada é; vemos um homem erguer-se em nosso caminho como um ponto de interrogação, sentimolo um tanto aborrecido e contudo, indefinidamente problemático. Que é a profundidade sob todas estas máscaras? Poderá ser o nada - o nada vasio e ôco - imbecilidade afetiva. Por trás de uma fachada silenciosa, que palpita incerta n'um humor vacilante, apenas ruinas, escombros, a ausência do espírito ou o hábito cortante da mais fria insensibilidade. Mas pela fachada não podemos prever o que atrás dela se esconde. Muitos esquizóides são como essas casas e vilas romanas que se fecham ao sol brilhante, enquanto na meia obscuridade do interior celebram festas". Descriminando as particularidades temperamentais dos esquizóides, Kretschmer os divide em três grupos: insociável, silencioso. reservado, sério, sem humor e extravagante; tímido, temeroso, delicado, sucetível, nervoso, irritável, amigo da natureza e dos livros; dócil, suave, sagaz, de humor estável, inerte, estúpido.

No primeiro grupo estão os caracteres mais frequentes, no segundo predominam os caracteres hiperestésicos e no terceiro, os insensíveis. Com relação à sociedade, êles podem ser absolutamente insociáveis, eclèticamente sociáveis e superficialmente sociáveis. Há, porém, desapego ao meio, marcando três atitudes em face da ambiencia. O hipersensível é introvertido para se livrar dos choques violentos da vida exterior, o insensível, porque as relações com o ambiente lhe são indiferentes, e o eclético, pela reunião dos dois elementos - hipersensibilidade e anestesia.

De outro lado, os ciclóides "sabem guardar, em tudo, a justa medida, o que torna as relações com êles tão agradáveis e preciosas. Têm prazer no trabalho e muita energia prática; mas esta energia é móvel e maleável; ela sabe se adaptar às circunstâncias e delas se impregna. Ela nada tem de comum com esta tenacidade cega e perigosa que nós encontramos nos esquizóides" (Minkowski).

Bleuler, aceitando as idéias de Kretschmer, substituiu o têrmo ciclotímia pelo de sintonia, levando em consideração essa capacidade de vibrar em harmonia com o meio. E sabido como Kretschmer se esforçou por consolidar seus estudos e conclusões utilizando rico material, orientando-se no sentido de bem precisar as relações entre a estrutura corporal e os diversos tipos de temperamento e carater não só dentro do 
campo da patologia mental como dentro dos indivíduos normais. Passíveis embora de crítica muitas de suas conclusões, permaneceu inatingido o arcabouço fundamental de sua obra (Côrpo e Carater) sôbre que se baseiam as aquisições da modernta escola constitucionalística.

Muito se tem escrito sôbre o conceito de esquizofrenia latente e sua extraordinária importância, sobretudo em psiquiatria forense. Há tendência em identificá-lo com o de esquizoidia de Kretschmer, afirmando Minkowski que "a esquizof renia latente dá lugar, em parte pelo menos, à esquizoidia de Kretschmer". "A esquizofrenia latente parece uma pedrinha no grande monumento que é a esquizofrenia. Entretanto, afigura-se-nos dele o pórtico. E pelas suas colunas e pelo estilo de suas linhas que o edifício se caracteriza, íntegro, na psicose manifesta; parcialmente construido ou demolido, nas remissões e nos estados prodrômicos" (Heitor Peres) ${ }^{6}$.

Bleuler, nos seus primeiros estudos, opinava ser a esquizofrenia latente um aspecto atenuado da psicose esquizofrênica. Todos os elementos fundamentais da doença eram lá encontrados em forma mitigada. Após os estudos de Kretschmer, porém, ampliou seus antigos pontos de vista. Com efeito, afirma êle: "encontramos nos esquizof rênicos antes da eclosão declarada da afeç̧ão, assim como nos membros de sua família, particularidades de existência bem características. Estas particularidades são inteiramente semelhantes àquelas que apresentam os doentes como residuo de um acesso anterior; ademais, qualitativamente, elas são da mesma natureza que os sintomas de uma esquizof renia manifesta" ${ }^{3}$. Tal conceito é idêntico ao de esquizoidia de Kretschmer, que, aliás, é combatido por Bumke ${ }^{7}$. Para êste autor, a esquizof renia é uma reação exógena, independente do fator terreno. São, porém, os autores franceses que mais têm estudado a fase prodrômica da demência precoce ou esquizofrenia. Assim é que assimilaram a noção de heboidofrenia de Kahlbaum que é mais ou menos semelhante ao período médico-legal da demência precoce de Antheaume e Mignot. Como se vê, todos esses quadros (esquizoidia, algumas esquizomanias, heboidof renias e período médico-legal de Antheaume e Mignot) tendem a se confundir na latência esquizofrênica.

Qual será, entretanto, o decurso da esquizof renia latente? Evoluirá fatalmente para a esquizofrenia? Bleuler afirma que ela poderá permanecer nesse estado durante toda a vida do indivíduo, dando apenas o aspecto extravagante e esquisito, há pouco descrito. Aliás, afirma o mesmo autor que essa parada na evolução é a forma mais frequente.

6. Peres, H. - A esquizofrenia latente e sua importância médico-legal. Em "Novidades em doenças mentais", Prof. H. Rôxo e colaboradores, Ed. Atlântida, Rio, 1934.

7. Bumke, O. - Tratado de las enfermidades mentales. Tradução da $2 .^{\mathrm{a}}$ edição alemã, Barcelona, 1927. 
Em outras ocasiōes, caminhará para a esquizofrenia franca, podendo também evoluir por surtos, como Kraepelin já havia assinalado. Mau grado certas remissões espontâneas ou terapêuticas, afigura-se-nos que o arcabouço esquizof rênico é de certa forma (pelo menos nas processuais) irremovível, não raro persistindo o que $\mathrm{Mauz}^{8}$ denominou "defeito esquizof rênico".

Em sua concepção dualista, Claude ${ }^{9}$, admitindo de um lado o conceito de demência precoce de Kraepelin e de outro, o grupo das esquizoses cuja forma extrema seria a esquizof renia no sentido de Bleuler, criou o novo conceito de esquizomania, forma de transição entre esquizoidia e a esquizof renia. Nela gozariam papel predominante os devaneios mórbidos e uma particular rigidez, irritabilidade de caráter, com traços de egoismo, orgulho, mau humor habitual, cóleras fáceis, dificuldade em suportar a menor contrariedade, a que Borel ${ }^{10}$ denominou "bouderie morbide". Posteriormente Claude, Robin, Rabinovitch ${ }^{11}$ descreveram uma forma que denominaram esquizomania simples. Segundo a crítica de Minkowski, endossada, aliás, pela maioria dos psiquiatras contemporâneos, toda a rica casuística de esquizomanos publicada pela escola de Santana se deixa facilmente englobar no conceito de esquizofrenia, visto que os casos publicados, a maioria deles com os caracteres de esquizof renia simples, apresentavam igualmente sinais da série hebefrêno-catatônica. Com algumas restrições talvez à grande extensão que dá Bleuler ao quadro das esquizofrenias, pretendendo incluir nelas a paranóia, a parafrenia e outros quadros imprecisamente delimitados, somos de opinião que realizou a concepção bleuleriana grande progresso no campo da psiquiatria, sobretudo no que diz respeito ao estudo psicopatológico dos esquizof rênicos. Muitos problemas permanecem ainda na obscuridade, tais como a etiologia — orgânica ou psicológica - sôbre que se debatem correntes organicistas e psicológicas, o problema dos decursos típicos e atípicos que foram estudados principalmente por Kleist e Leonard e, por fim, problemas de ordem terapêutica a que os modernos métodos de choque - convulsivante e insulínico em suas técnicas puras e combinadas - trouxeram grande e inegável progresso. Em todo êsse importante e complexo campo destaca-se, sem dúvida, o problema do diagnóstico precoce, para o que urge o conhecimento das manifestações iniciais da psicose, não só pelo melhor pro-

8. Mauz, F. - El prognostico de las psicosis endogenas. Tradução castelhana por Luiz Valenciano, Javier Morata, Madrid, 1931.

9. Claude, H. - A propos de la schizoidie et de la schizophrenie. An. Méd. Psychol. 84: 322-354 (Abril) 1926.

10. Borel, A. - Rêveurs et boudeurs morbides. Journ. de Psychologie, 1925, Ix́gina 535.

11. Claude H. - Robin et Rabinovitch - La schizomanie simple. Ann Méd. Psychol. 2 (Deze,bro) 1925. 
gnóstico quando o tratamento é levado a efeito ainda nos estádios iniciais, como também pelo fato de ser esta fase a mais importante, do ponto de vista médico-legal.

\section{MANIFESTAÇÕES INICIAIS. O CRIME COMO SINAL PRE-CLINICO}

A verificação de graves delitos em pacientes não portadores de sinais psicósicos francos, mas que apresentaram, decorrido curto prazo, sintomas esquizofrênicos, atraiu a atenção dos autores para a possível existência da psicose, embora em estado latente, já na época em que foram levados a efeito os atos antissociais. Apurou-se e aprofundou-se, então, cada vez mais, a análise anamnéstica, a-fim-de se descobrir os mais precoces sinais que pudessem trair a existência da enfermidade. Segundo Kraepelin, poder-se-ia notar nas fases iniciais: apatia, indiferença, crises de arrebatamento e cóleras fáceis, negativismo alternando com extrema docilidade; importantes sintomas seriam a incapacidade para o trabalhıo, os distúrbios da atenção (Masselon) e o embotamento intelectual. Desordens da vida afetiva e do senso moral foram destacadas como sinais de relevo, estas últimas ocupando primacial importância nas formas heboidofrênicas (Kahlbaum), suficientes mesmo para caracterizá-las. Segundo Abely ${ }^{12}$, os principais sintomas iniciais seriam: conciência do estado mórbido, sentimento de transformação da personalidade, idéias de influência e crises de ansiedade, exaltação dos instintos, sobretudo do sexual, com certa tendência para o pensamento e a linguagem abstratos. Roncati ${ }^{13}$ insiste sôbre a cefaléia, a sensação de constrição na fronte, de fadiga e esgotamento, preocupações hipocondríacas, alegando os enfêrmos que suas idéias se tornam confusas, com tendência ao isolamento e irritabilidađe. Heuyer e colaboradores ${ }^{14}$ dão particular importância ao déficit intelectual no início da esquizofrenia, aceitando, como os diversos autores, a importância das perturbações do caráter. Os pacientes se tornam rebeldes, em atitudes rígidas e hostís para as pessoas da família, já havendo, nesta fase, perturbações da vida afetiva que tanto caracterizam os portadores de esquizof renia. Para Régis ${ }^{15}$, a demência precoce se iniciaria, segundo quas formas princi-

12. Abély, X. - Les symptômes criminels de la démence précoce. Ann. Méd. Psychol, 84 : 147-160 (Junho) 1926.

13. Roncati, C. - Sintomi inizialissimi della demenza precoce-Schizofrenia. Referata em Zbl. Neur. u. Psych. 71:261 (Maio) 1934.

14. Heuyer, G. et Lequillant - Le début de la démence précoce. Resumo em Ann. Méd. Psychol. 2: 2561933.

Heuyer et M11. Serin - Les troubles du caractère au début de la démence précoce. Ann. Méd. Psychol (Julho) 1930.

15. Régis, E. - Précis de Psychiatrie. Gaston Doin, Paris, 1923. 
pais: começo agudo, por um acesso de confusão mental e começo lento e gradual, êste caracterizando a forma degenerativa. Nessa ordem de idéias concebeu a demência precoce como quasi sempre uma confusão mental crônica. Segundo Bleuler, o começo da esquizofrenia é, na maioria das vezes, insidioso. "Embora a enfermidade se torne manifesta aos olhos dos parentes por uma explosão aguda, uma bôa anamnese quasi sempre revela modificações do caráter ou outros sinais esquizofrênicos. Se a tendência que chama a atenção na idade infantil unida a certo grau de excitabilidade é a expressão de uma disposição ou o princípio da doença é cousa que não se pode resolver. Na maioria dos casos expressa-se pròpriamente a doença por uma perda gradual da capacidade e do poder de trabalho: em outros casos, sintomas neurastênicos, histéricos ou compulsivos surgem durante muito tempo como enfermidade e são inutilmente tratados (grifos do autor); as anomalias de caráter e os atos imotivados nos impressionam" (Bleuler) ${ }^{3}$.

Vários autores insistem sôbre a exteriorização de síndromes neuróticas (histerias, estados de ansiedade, neuroses compulsivas, etc.) na fase prodrômica da esquizofrenia. Um de nós ${ }^{16}$ publicou dois casos respectivamente de neurose de angústia e neurose compulsiva, que evoluiram, em poucos mêses, para formas graves de esquizofrenia processual. Embora Meduna, Glaus, Steines e Strauss tenham acentuado a extrema raridade da associação da epilepsia com a esquizofrenia, alguns autores referem crises epilépticas marcando o início da psicose. Em sua bem elaborada tese, Lucena ${ }^{17}$ estuda as manifestações iniciais de 17 casos, distinguindo duas eventualidades principais. Em um primeiro grupo de doentes as manifestações primeiras da psicose confirmaram os dados já assinalados pelos clássicos: abandono das ocupações, inatividade, tendência ao isolamento e mutismo, indiferença e repulsa pelas pessôas da família, agitações motoras sem finalidade aparente e extravagantes, chôro e risos imotivados, negativismo, solilóquios, incoerência de conceitos, alucinações, idéias delirantes de autorreferência e interpretação, de influência, de grandeza e persecutórias, sordície, fugas, tentativas de suicídio, etc. Num segundo grupo, o quadro referido pelos familiares sugeria antes a idéia de outra entidade mórbida (estados psiconeuróticos, personalidades psicopáticas, certos aspectos da loucura maníaco-depressiva, estados parafrênicos, paranóides e confusionais). Os trabalhos de Berze, Gruhle e Engelson acentuam os fenômenos de despersonalização, quasi sempre a instalação da enfermidade se traduzindo por um sentimento de transformação da personalidade, como uma tonalidade de

16. Uchôa, D. M. - Neuroses préesquizofrênicas. Considerações em tôrno de dois casos. Arq. Ass. Psicop. S. Paulo 6 (Março-Junho) 1941.

17. Lucena, J. - Contribuição ao estudo de algumas manifestações iniciais dos esquizofrênicos. Tese, Recife, 1938. 
ânimo angustioso, com distúrbios cenestésicos e conciência de enfermidade.

Se, como já ficou referido, é de grande importância o estudo dos sinais precoces da esquizofrenia, há todavia casos em que não é aparente qualquer fenomenologia mórbida nos quais, entretanto, a prática de atos antissociais e mesmo delitos graves reveste-se de morfologia especial que aponta, sem dúvida, a existência de morbidez psíquica, embora latente. Isto é corroborado pela evolução para o estado de psicose franca, o comportamento delituoso traduzindo portanto a primeira e, não raro, a única manifestação da enfermidade. Legrand du Saulle estudou o período médico-legal da paralisia geral em que distúrbios de caráter, perversão do senso moral em nítido contraste com a vida anterior dos pacientes, caracterizavam a existência da grave enfermidade mental, embora até aquele momento não fosse ainda aparente a sintomatologia clínica. Essa concepção, tendo sido posteriormente ampliada para o campo da demência senil, mostrou-se fértil sobretudo no campo da psiquiatria forense, de vez que todo um grupo de atos antissociais, mesmo crimes graves - muitos deles de natureza sexual - puderam ser rotulados como de natureza mórbida, os infratores sendo passíveis de tratamento antes que de medidas de repressão penal.

Antheaume e Mignot estudaram o que denominaram periodo médico-legal da esquizofrenia: pacientes sem sinal psicósico qualquer, que perpetravam os mais variados delitos, evoluiam posteriormente para a esquizof renia. Sob o ponto de vista médico-legal, esta concepção é de grande interesse, porquanto estudos posteriores têm levado sempre à conclusão de ser esta a fase criminógena por excelência, em que delitos de sangue de graves proporções têm sido perpretados, com a definição e acentuação da sintomatologia clínica decrescendo a perigosidade dos pacientes. Josip Glaser ${ }^{18}$ estudou os crimes cometidos por 9 pacientes com esquizofrenia incipiente. Enı alguns casos não foi encontrado qualquer motivo para a ação delituosa; em outros, motivos triviais e fora de proporção com a gravidade do ato, que se revestia sempre de excessiva crueldade. Os criminosos permanecem indiferentes, sem manisfestarem remorso ou emoção, parecendo não compreender a importância e as consequências do ato cometido.

Hackfield ${ }^{19}$ recolheu dados referentes ao estudo de 38 criminosos da clínica de Mayer (Zurich). Os casos foram divididos em 3 grupos: os que cometeram crime enquanto sofriam de esquizof renia latente ou

18. Glaser, J. - Crimes cometidos por pacientes com esquizofrenia incipiente. Ztschr. f. d. ges. Neur. u. - Psych. 150:1 (Abril, 18) 1934. Referido em Year Book of Neurol. a. Psychiatry, End. 1934, pag. 399.

19. Hackfield, K. - Criminal behavior in insidiously developing Schizophrenia. Amer. J. Psychiat. 91 : 639 (Nov.) 1934. Referido em Year Book of Neurol. Pschiat. End. 1934, pag. 399. 
manifesta e foram sentenciados à Penitenciária ( 7 casos); os criminosos com esquizofrenia que foram tratados mèdicamente (13 casos), e criminosos do tipo "moral insanity", declarados responsáveis e internados na Penitenciária (12 casos). A vida de prisão agravou a psicose do grupo I; do grupo II, 76,9\% tiveram remissão e viveram fora da instituição, muitos sob supervisão médica; em nenhum caso as dificuldades da vida penitenciária precipitaram a psicose nos pacientes do grupo III. Conclue o autor que "durante as fases iniciais da esquizofrenia, pessôas que eram anteriormente ajustadas econômica e socialmente, podem cometer crimes atrozes, comumente tais atos sendo de ininteligivel motivação. Tais crimes, quando cometidos por pessôas que manifestam tendências primárias esquizóides, são sintomáticos de uma esquizofrenia latente".

Wilmanns ${ }^{20}$, discutindo o impulso para matar durante a fase prodrômica e o estado de frieza e impassibilidade em que muitos réus permanecem até o momento de serem executados, friza não sofrerem êles de "moral insanity", mas estarem no período prodrômico da esquizof renia. A evolução desses casos para a esquizofrenia franca, que é muito encontradiça nos antigos autores de crimes de sangue violento, é mais um dado em favor do estado de morbidez psíquica em que já se encontravam êles ao perpetrarem tais atos. Gualter Lutz ${ }^{21}$ refere-se a um caso relatado por Adauto Botelho, em que considera justificável o diagnóstico de esquizofrenia latente: uma mulher matou a tiros de revólver, à noite, o seu companheiro, permanecendo, em seguida, obnubilada, com amnésia posterior em relação ao fato ocorrido. Algum tempo após, no Hospital Psiquiátrico do Rio de Janeiro, sobreveiu estado de indiferença com certa interiorização. Assim, há quasi unanimidade dos autores quanto à extraordinária importância do estudo psicopatológico dos réus que cometem delitos de grandes proporções com determinados caracteres (grande violência etc.), não raro tratando-se de verdadeiro sinal de alarme de uma psicose esquizofrênica ainda em fase muito precoce, sem qualquer sintomatologia aparente.

O material que apresentamos a seguir confirma plenamente tais opiniões e reveste-se, a nosso vêr, de grande importância, sobretudo à luz dos problemas médico-legais que sucita (responsabilidade criminal, temibilidade, perigosidade, tratamento e prognóstico etc.), opondo muitas vezes grandes dificuldades ao psiquiatra forense, ao juiz e ao legislador. Daí o interesse do seu estudo.

20. Wilmanns, K. - Crime na frase prodrômica da esquizofrenia. Ztschr. f. d. ges. Neurol. u. Psychiat. 170: 583-662, 1940. Referido em Year Book Neur. Psychiat. End. 1941, pag. 334.

21. Lutz, A. G. - Autoacusação, homossexualismo e transvestitismo. Tese, Rio de Janeiro, 1939. 


\section{OBSERVAÇÕES}

ObSERvaÇão 1 - A. M. branco, brasileiro, solteiro, lavrador, com 15 anos de idade, internado em 17 de setembro de 1934, no Manicômio Judiciário, procedente da Penitenciária do Estado.

Crime - A 10 de março de 1932, cerca de 10 horas, numa fazenda no municipio de Espírito Santo do Turvo, A. M. e um sobrinho cortavam madeira para construção de uma tulha, quando o último, em determinado momento, disse que "sabia de uma cousa mas que não podia falar". A. M., curioso, insistiu para que seu companheiro falasse, nada conseguindo porém. Pouco depois, com surpreza para A. M., o sobrinho tentou agredí-lo com um pau. Desviando-se rapidamente, A. M., que nêste instante tinha uma foice na mão, brusca e impulsivamente vibrou com ela forte golpe no agressor o qual veiu a falecer imediatamente. Preso, confessou o crime, segundo foi anteriormente exposto, acrescentando que, havia algum tempo, morava com um irmão casado, cuja espôsa vinha tentando seduzí-lo. Recusara sempre suas deshonestas propostas e, ante a frase da vítima anteriormente citada, julgou ter ela conhecimento do comportamento de sua mãe Por isso sentiu-se ansioso ante a atitude do sobrinho e, sem saber como, revidou com grande violência a inesperada agressão, ferindo-o mortalmente. Condenado a 15. anos de prisão celular, foi submetido a novo julgamento, tendo o juri reconhecido a seu favor a dirimente do artigo 27 , parágrafo $4 .^{\circ}$ da C. L. P., sendo posteriormente internado no Manicômio Judiciário (art. 29).

Pai alcoolista, um irmão doente mental. Aos 12 anos abandonou a casa paterna, por maus tratos que lhe infringia o genitor. Analfabeto, dedicou-se a trabalhos agrícolas. Do passado médico constam sarampo e paludismo. Tipo leptossômico. Nada de particular revelou o exame somático. Reações de sangue e líquido céfalo-raquidiano negativas para lúes.

Condições psłquicas - A observação psiquiátrica, elaborada em 16-12-1934, concluiu tratar-se de personalidade psicopática esquizóide (atitudes de introversão e rigidez afetiva, etc.), não havendo qualquer manifestação psicósica pròpriamente. $O$ paciente mostrou-se sempre lúcido, arrependido do crime perpetrado, sem sinais patológicos nas diversas funçōes psíquicas (atividade discursiva, sensopercepção, orientação, funções de julgamento e crítica).

Nova observaç̃̃o realizada 4 anos após (1938), assinalou agravação dos caracteres mórbidos: impulsos agressivos, perda total da iniciativa e capacidade para o trabalho, falta ce contacto com a ambiência, sendo feito o diagnóstico de "esquizofrenia, forma simples". Agravando-se sempre o seu estado, foi submetido aos métodos terapêuticos de Sakel (36 comas) e Meduna (12 ataques convulsivos), sem qualquer resultado apreciável. Faleceu a 15 de março de 1939 por moléstia intercorrente.

Conclusãa - Crime de natureza impulsiva. Personalidade esquizóide, sobrevindo posteriormente grave esquizofrenia processual.

OBSERVAÇÃo 2 - J. M. branco, brasileiro, barbeiro, solteiro, com 26 anos de idade, internado a 21 de março de 1938, no Manicômio Judiciário, procedente da Penitenciária do Estado.

História social e criminal - Nasceu a 12 de setembro de 1912 em Jaboticabal (S. Paulo). Criou-se em companhia dos pais até a idade de 15 anos, tendo frequentado com proveito escola primária. Aprendeu o ofício de barbeiro, sem todavia ter se dedicado a essa profissão. Filho ilegítimo, desde os 8 anos viveu sem pai, o qual foi para a Síria viver em companhia da verdadeira espôsa. Sem qualquer disposição para o trabalho, viveu grande parte de sua vida na mais completa vadiagem, sendo por isso detido várias vezes pela polícia. Em 1926, cometeu o 
primeiro furto em Olímpia, tendo cumprido ? meses de pri-ão. Ao sair do presídio, cometeu novos pequenos furtos, até oue. a 23 do majo do 193.? fai novamente preso em Rio Preto, por furto e roubo. Processado e condenado à pena de 5 anos, deu entrada na Penitenciária a 16 de junho de 1934.

Nada de particular quanto aos antecedentes hereditários. Contraiu sarampo, paludismo e blenorragia. Desenvolveu-se regularmente tanto do ponto de vista físico como psíquico. Logo após sua internação na Penitenciária, exteriorizou procedimento muito irregular. Um mês após, acusou sensações vertiginosas, fobiás, certo estado de ansiedade, estado êsse que remitiu alguns dias depois. Escalado para trabalhar numa das oficinas revelou pouca aplicação. Em dezembro de 1937, surgiram distúrbios psicósicos. Muito excitado, dizia-se "enviado de Deus para reduzir a pó todos os espíritos maus", sendo então removido para o Manicômio Judiciário. Normal funcionamento dos diversos aparelhos. Exames de sangue e líquido céfalo-raquidiano negativos para lúes.

Exame psíquico - Predomina um delírio megalomaníaco, místico; é um predestinado que, como Cristo, veio ao mundo cumprir grande missão, isto é, salvar a humanidade estando sempre em comunicação direta com Deus. Diz ter recebido a revelação de sua missão logo após ter entrado na Penitenciária. Além disso, distúrbios afetivo-volitivos (indiferença, ssolamento, perda da iniciativa, etc.).

Diagnóstico e Conclusõcs - E portador de uma síndrome de esquizofrenia paranóide, que, tudo leva a crêr, vem já evoluindo desde sua internação na Penitenciária. Sua rica atividade delituosa anterior alternando com períodos de vadiagem, sem qualquer iniciativa e disposição para o trabalho, não influenciada pelas várias medidas de repressão, assinalam o caráter de morbidez de tão irregular comportamento. Já era, sem dúvida, portador de sinais incipientes de esquizofrenia que evoluiria para uma forma paranóide, esta não se modificando apreciàvelmente até o presente momento. Em suma: múltiplos delitos (vadiagem, furto, roubo) numa fase incipiente (preclínica) de esquizofrenia, evoluindo, em seguida, para uma forma paranóide.

ObSERVAÇÃo 3 - A. B. branco, brasileiro, solteiro, pedreiro, com 34 anos de idade, internado no Manicômio Judiciário em 28 de outubro de 1936.

Crime - “Em 1 de agosto de 1936, em Monte Aprazível, onde residia, A. B. feriu, com um golpe de navalha, a J. B. G. Não houve motivo algum para o crime. A própria vítima não sabe explicá-lo" (Da denúncia). Nas declarações que fez na Delegacia de Polícia local, o acusado alegou que, nesse dia pela manhã, havia sido procurado por J. B. para combinarem reparos na casa deste. Feita a vistoria, A. B. retirou-se após ter tomado uma chícara de café. Chegando em sua casa, momentos depois sentiu-se adoentado e resolveu tomar um laxativo. Seu estado peorou, tendo por isso procurado um médico. Acamou-se, desconfiado porém que J. B. "tivesse deitado qualquer ingrediente no café, que motivara a doença, pois, pela manhã estava bem de saúde"; ao escurecer, J. B. foi à procura de A. B. que no momento se sentia mal, quando êste, guiado pela interpretação recente, se levanta com uma navalha e agride o amigo que o procurava. Desarmado pela mãe, A. B., em seguida, deita-se calmamente ante o chôro dos irmãos e mãe que perceberam a gravidade do ato; pouco depois, era preso e conduzido à Delegacia. O acusado afirmou que, conquanto não fosse amigo da vítima, era seu conhecido há muito tempo e nunca com êle tivera qualquer desavença.

Pai alcoolista imoderado desde tempos anteriores ao nascimento do examinando. Mãe sadia. Nove irmãos vivos e três falecidos. Há cerca de 2 anos, contraiu paludismo. Sempre foi muito retraido, estado êsse que se acentuou de 2 anos a esta parte. Permanecia sempre em casa, sòmente saindo à rua para 
serviço au por necessidades imperiosas. Condições físicas sem nada de particular. Reaçōes no soro sanguíneo e no liquor negativas para lúes.

Condições psíquicas - A observação psiquiátrica elaborada a 27 de fevereiro de 1937 concluiu tratar-se de uma esquizofrenia, forma simples (distúrbios afetivovolitivos, perda da capacidade para o trabalho, raras alucinaçōes auditivas, ambivalência, atitudes de introversão e autismo). Desinternado para conlusão do processo, foi absolvido e reinternado no Manicômio Judiciário (artigo 29) em $10^{\circ}$ de rutubro de 1938, quando novo exame mental confirmou o diagnóstico de esquizofrenia, forma simples. Cerca de 2 anos após, entravam em remissão os distúrbics psicósicos, permanecendo atualmente os sinais fundamentais de personalidade esquizóide.

Conclusões - Agressão irracional (sem motivação aparente) ; indiferença posterior quanto ao ato praticado, atitude esta logo secundada pelos sintomas fundamentais da psicose esquizofrênica.

Observaç̃̃o 4 - A. D. branco, brasileiro, lavrador, solteiro, com 25 anos de idade, internado no Manicômio Judiciário a 9 de setembro de 1936.

Crime - Na noite de 24 para 25 de janeiro de 1935 , na residência de S. G., distrito de Vila Fortunata, comarca de Assis, onde se realizava um baile, A. D., inesperadamente, agrediu a navalha J. M. S. que dansava com a menor B. A. Em seguida, dirigiu-se para sua residência, recolhendo-se ao leito. Despertado e interpelado nelo pai, respondeu nada ter feito. Em suas declarações no dia imediato na sub-delegacia do mencionado distrito, referiu ter perpetrado o crime em virtude de ter observado que "a vítima ransava de modo inconveniente".

Criou-se em companhia dos seus, dedicando-se sempre ao serviço da lavoura. Năo conta em seu passado qualquer ato antissocial, o examinando sempre tendo revelado perfeita adaptação ao meio em que viveu. Antecedentes médicos sem importância. Tipo leptossômico. Satisfatórias condições físicas.

Exame mental - Desorientação alopsíquica, perda de contactc com o meio, autismo, alucinações auditivas entretendo delírio persecutório; frequentes fenômenos de interceptação do pensamento, respostas inadequadas (absurdas, incoerentes).

Diagnóstico e Conclusões - Esquizofrenia processual (ausência de qualquer modificação até o presente momento pelos métodos terapêuticos de Von Meduna, Sakel e Georgi). O examinando perpetrou um delito grave durante um baile, a tcdos surpreendendo pela repentinidade e imotivação do ato, tanto mais que, até aquele momento, não exteriorizara qualquer anomalia mental, tendo tido sempre ótimo comportamento. A morfologia do crime, sua atitude imediatamente após o mesmo, onde ressalta a completa indiferença ante tão grave ato e a irrupção, pouco tempo após, das acentuadas desordens psíquicas de tipo esquizofrênico de que é portador até o momento atual, fazem-nos concluir ter sido o ato delituoso o primeiro sinal de uma esquizofrenia ainda em fase prodrômiça.

ObServação 5 - M. O. F. branco, brasileiro, solteiro, com 27 anos de idade, internado no Manicômio Judiciário em 18 de junho de 1935.

Crime - $\mathrm{Na}$ noite de 10 de dezembro de 1934, M. O. F. pediu pouso e alimentação na Fazenda “Iguatemizinho", em Monte Santo, comarca de Mogí-Mirim.

No dia seguinte, foi trabalhar na roça, mas, como o seu serviço não rendesse, mandaram-no descascar milho no paiol; o administrador, de quando em vez, o repreendia por ser pouco produtivo. No dia 12 pela manhã, o acusado resolveu matá-lo, o que fez com dois golpes de enxada. Utilizando-se de um canivete que se encontrava no bolso do cadáver, cortou uma das orelhas do mesmo, colocando-a num dos seus bolsos. Fechou depois a porta do paiol e, passando pela sede da fazenda, levou consigo um chapeu. Dirigiu-se, em seguida, para outra fazenda, 
no dia seguinte tendo sido detido por suspeitarem que era ladrão. Ao ser revistado, foi encontrada uma orelha humana num dos seus bolsos. Preso referiu em suas declarações que cortara a orelha do cadáver porque a própria vítima lhe havia dito "que era bom guardar orelhas dos outros no bolso". Dias depois, no sumário, o seu comportamento despertou suspeita de que era portador de distúrbio mental, sendo então internado no Manicômio Judiciário para exame psiquiátrico.

Nada de particular quanto a taras psicopáticas e antecedentes mórbidos pessoais. Havia 6 anos, transferíra-se da Bahia para êste Estado, onde trabalhou ęm várias fazendas como colono. Desde um ano antes do crime, já não exercia qualquer atividade. Tipo leptossômico. Satisfatórias as condições físicas. Exames do sangue e do liquor negativos para lúes.

Estado mental - A observação psiquiátrica elaborada em 24 de outubro de 1935 concluiu tratar-se de esquizofrenia processual, forma catatônica (mutismo, sitiofobia, abulia, autismo, negativismo, catalepsia, sordície). Pouco tempo após, sobreveiu franco estado domencial, mau grado vários tratamentos empreendidos (métodos de Sakel, Meduna, etc.).

Conclusōes - Crime sem motivação aparente com requintes de sadismo numa personalidade que não exteriorizara até aquele momento qualquer sinal de morbidez mental, e que, no entretanto, pouco tempo após (ainda no sumário) apresentou forma grave, processual, de esquizofrenia.

ObSERVAÇÃo 6 - T. S. amarelo, solteiro, japonês, com 32 anos de idade, internado no Manicômio Judiciário em 30 de julho de 1934.

Crime - $\mathrm{Na}$ madrugada de 5 de dezembro de 1929, no quilômetro 16 da estrada de José Theodoro ao Rio Pardo, num rancho onde moravam, T. S. desfechou um tiro de revólver no ouvido direito de S. K., seu patrício e companheiro, que dormia. Ao prestar declarações, alegou como causa de sua atitude, o mêdo que the inspirava S. K., pois o ameaçara de morte. Condenado pelo Juri de Presidente Prudente à pena de 6 anos, entrou na Penitenciária a 7 de janeiro de 1932. A observação aí elaborada verificou tratar-se de personalidade esquizóide. A 31 de agosto de 1932, surgiram distúrbios mentais que mais e mais se agravaram, condicionando sua remoção para o Manicômio Judiciário. A observąção i)siquiátrica aí elaborada, a 29 de de novembro de 1943, concluiu tratar-se de esquizof́renia, forma simples (desorientação alopsíquica, distúrbios afetivo-volitivos com grande indiferença ao meio e, por vezes, atos extravagantes, alucinações auditivas cintretendo delírio persecutório sem sistematização). Não foi apurado qualquer dado de interesse sob o ponto de vista físico e no que diz respeito aos seus antecedentes médico-sociais.

Conclusões - A morfologia do delito, seu caráter irracional (a alegação do criminoso foi evidente racionalização) denotam tratar-se já naquela época de tim psiquismo mórbido. Ao ingressar na Penitenciária, caracterizou-se a personalidade esquizóide, pouco tempo após surgindo graves desordens psíquicas de tipo esquizofrênico. Posto tenha decorrido cerca de 2 anos entre o delito e as primeiras manifestaşões mórbidas, concordamos com a opinião do ilustrado psiquiatra (Dr. Moraes Melo) que o examinou na Penitenciária, quando admite uma relação de causa e efeito entre o estado psicopatológico do examinando e o bárbaro crime. Julgamos portanto ter sido perpetrado o delito numa fase ainda prodrômica da esquizofrenia.

ObServação 7 - P. N. branco, brasileiro, casado, com 27 anos de idade, operário, internado no Manicômio Judiciário em 16 de fevereiro de 1932, procedente da Penitenciária do Estado. 
Crime - No dia 19 de fevereiro de 1928, cerca de 21 horas, na comarca de Taquaritinga, numa venda onde se achavam reunidas diversas pessôas, $P$. N., sem qualquer motivo aparente, sacou de uma arma de fogo, disparando-a contra J. F. Foi atingida a regiăo escapular esquerda, a bala alcançando igualmente E. J., no braço esquerdo. Em seguida, o agressor aproximou-se rapidamente da primeira vítima e, com novo disparo à queima roupa atravessou-lhe o coração. $O$ juri da Comarca de Taquaritinga condenou-o a 6 anos de prisão celular, tendo sido internado na Penitenciária em 3 de fevereiro de 1930.

Antecedentes sem importância clínica. Condiçōes físicas satisfatórias. As reações no sangıe e no líquido céfalo-raquidiano foram negativas para a lúes.

Estado mental - Logo ao ingressar na Penitenciária, apresentou uma síndrome catatônica. A observação psiquiátrica elaborada no Manicômio Judiciário a 30 de junho de 1932, concluiu: perda do contacto vital com a realidade, ideação e atos extravagantes, estereotipia, síndrome de Ganser, flexibilidade cérea, automática, risos sem motivação aparente, atos impulsivos. desorientação alopsíquica.

Diagnóstico e conclusóes - Esquizofrenia. Trata-se de um crime violento, peipetrado sem motivo aparente por individuo que, até aquele momento, não apresentara qualquer distúrbio mental. Pouco tempo após, irrompeu uma forma grave de esquizofrenia que, mau grado vários tratamentos empreendidos, não apresentou qualquer modificação. $\mathrm{O}$ aspecto brusco $\mathrm{e}$ impulsivo do crime, sua imotivação e extrema violência, e o fato de, pouco tempo após, ter o paciente exteriorizado uma forma grave de esquizofrenia processual, são elementos que indicam ter sido o ato criminoso levado a efeito durante o período prodrômico da psicose.

ObSERVAÇão 8 - J. D. branco, brasileiro, viúvo, com 33 anos de idade, pintor, internado em 11 de julho de 1934, no Manicômio Judiciário, proveniente da Penitenciária do Estado.

Crime - A 28 de outubro de 1928, 11 dias após o matrimônio, em sua residência em Campinas, J. D., após discussão com sua espôsa, desferiu-lhe três golpes de faca, em consequência dos quais teve ela morte quasi instantânea. Em seguida, tentou suicidar-se, ferindo-se no peito com a mesma arma. Condenado à pena de 16 anos e meio de prisão celular, deu entrada na Penitenciária a 19 de agosto de 1931.

Pai falecido, vítima de "ataques". A genitora, falecida, havia apresentado distúrbios mentais anteriormente. Contraiu sarampo, parotidite, cancros venéreos, com adenite supurada e reumatismo monoarticular febril. Apresentou um processo de tuberculose pulmonar de que ficou clínicamente curado. As reações procedidas no sangue e no líquido céfalo-raquidiano foram negativas para a lúes.

Estado psíquico - Pouco tempo após sua internação na Penitenciária, apresentou acentuada depressão psíquica, com fenômenos de ansiedade. Removido para - Manicômio Judiciário, a observação psiquiátrica elaborada a 19 de setembro de 1934, assinalou idéias delirantes de influência não sistematizadas, conceitos extravagantes, absurdos, denotando acentuada desagregação psíquica, desorientação quanto aos dados do meio, lugar e tempo, apatiz, alucinações auditivas, absoluta indiferença ante o crime cometido, e múltiplas manifestações discordantes.

Diagnóstico $c$ Conclusões - Psicose esquizofrênica. Uxoricídio 11 dias após o matrimônio, no decurso de uma discussão com a esposa, levado a efeito com grancle violência e seguido de tentativa séria de suicídio (o paciente ficou gravemente ferido pelos seus próprios golpes de faca). Até aquele momento, não apresentava qualquer sinal slínico de doença mental. Algum tempo após, surgiu o estado depressivo-angustioso, logo seguido por manifestações graves de tipo esquizofrênico. Até o presente momento não houve qualquer modificação no seu 
estado mental, confirmando-se sempre o diagnóstico anterior. Crime perpetrado na fase prodrômica da esquizofrenia,

ObSeRvaç̃̃o 9 - D. M. branco, brasileiro, solteiro, com 27 anos de idade, lavrador, internado em 17 de setembro de 1934, no Manicốmio Judiciário, proveniente da Penitenciária do Estado.

Crime - A 30 de maio de 1931, no município de Jardinópolis, D. M., durante um baile, pretendeu dansar com certa moça, tendo sido por ela recusado. No dia imediato, cerca de 16 horas e meia, tendo-lhe dito um amigo que aquele insulto se pagava com a morte, D. M., armou-se com um revólver, e, alcançando 2 jovem em determinada rua, segurou-a pelos braços e desfechou-lhe três tiros, produzindo-lhe morte instantânea. Condenado à pena de 12 anos de prisão celular, foi transferido para a Penitenciária em 3 de maio de 1932.

Nada apuramos de anormal quanto aos antecedentes hereditários e pessoais. Bôas condiçôes somáticas. Reações sorológicas negativas para sífilis.

Estado mental - Ainda no período de prova na Penitenciária, instalou-se franco delírio persecutório, motivando sua remoção para o Manicômio Judiciário. Aí a observação psiquiátrica de 2 de dezembro de 1934, assinalou: idéias delirantes persecutórias e megalomaníacas, amaneiramentos, associação ideativa extravagante, fenômenos de automatismo mental (éco sonoro e roubo do pensamento).

Diagnóstico e Conclusões - Esquizofrenia. Crime violento com motivação iutil de todo desproporcionada com a agressão, levado a efeito por um indivíduo aparentemente sem qualquer desordem mental. Preso pouco tempo após, surgiram distúrbios graves do psiquismo sob forma de uma psicose esquizofrênica. Submetido ao método de Meduna (21 crises convulsivas) e ao método de Sakel (40 comas insulínicos), não obteve a princípio qualquer melhoria, que, todavia, sobreveiu tardiamente, possibilitando sua remoção para a Penitenciária a 4 de junho de 1941.

Observação 10 - I. B. branco, brasileiro, solteiro, com 18 anos de idade, lavrador, internado no Manicomio Jud ciário em 11 re dezembro de 1935.

Crime: A 14 de julho de 1935 , no município de Piracicaba, I. P. S. feriu, a golpes de navalha, V.S., seu companheiro de serviço, produzindo-lhe graves lesões. A vítima, após o primeiro golpe, fugiu, tendo sido perseguida pelo paciente que the desfechou nova navalhada pelas costas. Segundo as várias peças do processo, o paciente comprara da vítima uma navalha pelo preço de $5 \$ 000$, recusando-se a pagar porque o objeto adquirido estava com o cabo quebrado. Ante a insistência do vendedor, reagiu, atacando-o com violência.

Antecedentes sem importância clínica. Nada de particular ao exame dos diversos aparelhos. Sangue e líquido céfalo-raquidiano negativos para a lúes.

Exame psíquico - O laudo elaborado a 8 de abril de 1936 revelou desorientação alopsíquica, autismo, respostas lacônicas, apatia, amaneiramento, atos impulsivos, sendo perigoso o convívio com os companheiros. Inversão sexual.

Diagnóstico e Conclusões - Esquizofrenia, forma simples. Agressão violenta pur motivo futil, de tipo impulsivo, por parte de um indivíduo sem qualquer desordem mental aparente, pouco tempo após surgindo franca sintomatologia esquizofrênica, inalterada até o momento atual.

ObServaçÃo 11 - M. S. V. branco, português, solteiro, com 30 anos de idade, operário, internado em 16 de fevereiro de 1932 no Manicômio Judiciário, procedente da Penitenciária.

Crime - A 23 de janeiro de 1930, na Capital (S. Paulo), cerca de 21 horas, ao passar perto do seu companheiro de residência, J. A. ouvira deste as palavras 
"sae azar". M. S. V. sacou imediatamente do revólver, alvejando-o pelas costas duas vezes, a vítima tombando agonizante. Em seguida, M. S. V. muniu-se de uma picareta e vibrou-lhe ainda, com esta, violento golpe na cabeça, fugindo após. No dia imediato, foi o agressor encontrado numa várzea gravemente ferido no ouvido direito, por tentativa de suicídio com arma de fogo. Preso a 21 de sctembro de 1930, condenado a 6 anos de prisão celular, deu entrada na Penitenciária a 28 de setembro de 1931.

Antecedentes hereditários e pessoais sem nada de particular. Leve cicatriz acima do tragus com 2 semi círculos de incrustações de pólvora (ferimento produzido por projetil de arma de fogo no ouvido direito, havendo assimetria facial. Lesão periférica?). Nada mais de particular no exame somático. Exames de sangue e líquor negativos para a lúes.

Exame psiquico - Ainda no período de prova na Penitenciária, apresentou grande crise de excitação psicomotora, com atos de destruição e agressão, sobrevindo depressão e mutismo. Removido para o Manicômio, a observação elaborada em 29 de junho de 1932 assinalou: mutismo dificilmente redutível, estereotipias, atos extravagantes, indiferença afetiva alternando com estados de irritabilidade, de depressão e paroxismos de excitação.

Diagnóstico e Conclusões - Esquizofrenia. Crime com alta violência e im1,ulsividade, reação bastante desproporcionada ao estímulo, com tentativa de suicídio posterior, numa personalidade que até aquele momento não apresentava distúrbio mental caracterizado. Pouco tempo após, surgiram graves manifestações de tipo esquizofrênico que perduraram, sem qualquer modificação, até 13 de maio de 1936, data de seu falecimento por tuberculose intestinal.

ObSERvação 12 - K. M. japonês, viúvo, com 47 anos de idade, procedente de Penapolis, internado no Manicômio Judiciário a 9 de janeiro de 1927.

Crime - Em 28 de maio de 1926, em uma choupana, situada em Penápolis, K. M. assassinou, a polpes de machado, sua espôsa e seus quatro filhos menores (respectivamente de 9,11, 14 e 16 anos de idade) sem qualquer motivo aparente. Em seguida, apresentou-se aos visinhos de sua residência espontaneamente, confessando o crime. A êstes declarou que sua espôsa e filhos, tomados de terror, dlta noite, por causa de grande chuva que caia, pediram-lhe que os matasse pois temiam ser assassinados por um ladrão. Fez então com que todos se deitassem pela ordem das idades, começando pelo filho mais moço, estando em último lugar sua espôsa, seguindo-se a série dos múltiplos crimes. Em suas declarações na Delegacia de Polícia local, referiu que, ùltimamente, se sentia muito nervoso, em virtude de questōes referentes ao sítio de sua propriedade, alimentando-se e dormindo insatisfatòriamente. Pouco antes do crime, na madrugada de 28 de maio, tivera um sonho de angústia: vira fogo no quarto e sentira acentuada dôr na região lombar sentindo angústia e mêdo. Tomado de pavor, dera um ponta-pé na mala junto à sua cama, despertando a família com tal ruido. Foi nessa ocasião, quando copiosamente chovia, que sua família, já desperta, tomada de pavor, teria pedido a K. M. que lhes tirasse a vida. Perpetrado o crime, deitou-se sôbre um dos cadáveres, adormecendo por certo tempo. Ao despertar, tomou alguns objetos, inclusive dinheiro, indo às casas dos visinhos onde revelou o bárbaro $\mathrm{e}$ extranho crime.

Preso, foi examinado poucos dias depois, por peritos da localidade que mencionaram: sitiofobia (por receio de ser envenenado), automutilação, crises de excitação motora, insônia, indiferença afetiva, o paciente tendo narrado todo o crime sem qualquer exteriorização de ordem emocional. O exame procedido no Manicômio confirmou tratar-se de esquizofrenia, os peritos concluindo ter sido o delito perpetrado durante a fase prodrómica ou médico-legal da psicose. Aliás, segundo dados anamnésticos colhidos, não apresentara o examinando, até a data 
do delito, qualquer sinal psicopatológico, trabalhando e vivendo normalmente com sua família. O crime foi portanto o primeiro sintoma da grave psicose que posteriormente irrompeu com a clássica fenomenologia da esquizofrenia.

Observaçño 13 - J. B. branco, sírio, viúvo, com 32 anos de idade, comerciante, internado em 1 de janeiro de 1925, no Manicômio Judiciário, para exame de sanidade mental.

Crime - Na cidade de Araraquara, no dia 11 de junho de 1924, saíu de sua residência,dirigindo-se para a casa de sua irmã, com intenções, segundo depôs uma-testemunha, de embarcar nesse dia com destino à Síria. Não tardou qu? sua irmã J. B. aparecesse e, tomando-a pelo braço, conduziu-a até o quintal, cnde lhe desfechou 15 facadas. Procurou depois esconder o cadáver e fingiu, auxiliado por amigos. Onze dias após, foi preso no município de Itápolis. $\mathrm{Na}$ polícia, confessou o delito, referindo que encontrara sua irmã conversando com um desconhecido, e que, ao falar com ela, foi agredido no rosto com um sapato. Ademais, há muito, tinha notícias de que sua irmã não procedia bem na Síria donde viera há pouco tempo. O exame pericial procedido no caso verificou tratar--se de uma virgem, tendo tambem sido afastado a hipótese de agressão com o sapato, pois que os mesmos se conservavam em seus pés. Ademais, a vítima não falava o português e, se estivesse conversando com algum desconhecido, deveria ser um sírio. Ficou assim demonstrado serem inverídicas as alegações do criminoso.

Pais sadios. Um tio, falecido, era epiléptico. O paciente sempre se mostrou reservado, esquivo para com os circunstantes. Era, ademais, violento e, por vezes, dava-se ao uso de alcool. Um ano antes do delito, tornou-se irritado, colérico e falava constantemente na deshonra da família, alegando que sua irmã não procedia bem. Condições físicas sem nada de particular. Sangue e línuido céfalo-raquidiano negativos para a lúes.

Exame psíquico - O laudo elaborado em 7 de março de 1925 revelou desagregação do pensamento, atenção instável, desorientação no tempo, delírio persecutório sem sistematização, alucinações auditivas verbais, ilusões visuais e estado de humor depressivo na maior parte das vezes, havendo porém períodos de excitação. Apatia, indiferença e nula capacidade para o trabalho.

Diagnóstico e Conclusões - Esquizofrenia, forma paranóide. Delito violento, impulsivo, imotivado ao que parece, tendo surgido poucos meses após graves distúrbios de caráter esquizofrênico, o que levou os peritos a afirmar que o mesmo havia sido cometido no chamado período médico-legal da esquizofrenia.

Observação 14 - A. N. branco, itałiano, casado, com 40 anos de idade, operário, internado no Manicomio Judiciário em 10 de agosto de 1939, proveñiente da Casa de Detenção da Capital.

Crime - A 30 de maio dé 1938 , cerca de 7,30 horas, no depósito da firma I.R.F.M. desta Capital, A. N. empenhou-se em luta corporal com A. D., ferindo-o mortalmente a navalha. Em suas declarações, alegou que a vítima o prowocara, tendo então se queixado ao gerente. Irritada com tal atitude, teria a vítima pronunciado certa frase irônica indiretamente dirigida a êle. Este então reagiu violentamente, tendo sido levada a efeito a cêna criminosa. Incurso nas penas do artigo $294 \S 2 .^{\circ}$ da C.L.P., foi recolhido à Casa de Detenção da Capital. Logo após a entrada, seu comportamento foi se tornando anormal, surgindo distúrbios graves, o que motivou sua remoção para o Manicômio.

O laudo aí elaborado a 5 de janeiro de 1940 revelou: mutismo periódico, ambivalência afetiva, autismo, várias atitudes negativistas, idéias delirantes de perseguição, excitação psicomotora, gatismo. Foi formulado o diagnóstice de es- 
quizofrenia. Até o momento atual, não houve qualquer modificação no estado mental, confirmando-se sempre tratar-se de uma forma grave da psicose referida. Nada de particular quanto aos antecedentes hereditários. Apresentou uma plauzite com derrame de que se restabeleceu. Os exames de sangue e líquido céfalo-raquidiano foram negativos.

Conclusão - Agressão violenta por motivo futil de que resultou morte do ofendido, levada a efeito por indivíduo até o momento sem distúrbio psíquico aparente, surgindo pouco tempo após grave psicose esquizofrênica, forma processual, que persiste até o momento atual.

ObSERVAção 15 - B. E. branco, brasileiro, solteiro, operário, com 23 anos de idade, internado no Manicómio 'Judiciário em 22 de setembro de 1931, procedente da Penitenciária do Estado.

Crime - No dia 14 de julho dé 1926, no município de Albuquerque Lins, B. S., armado de machado, invadiu o rancho onde residia C. S., produzindo-lhe ferimentos graves enquanto êle dormia, de que resultou a morte do ofendido. Declarou o criminoso que tivera discussão anteriormente com a vítima, e, como esta continuasse a provocá-lo, na véspera resolvera assassiná-la, o que fez a golpes de machado, refugiando-se, em seguida, em casa dum amigo. Preșo, foi condenado a 5 anos de prisão celular, sendo removido para a Penitenciária a 4 de março de 1927. Ainda no período de prova, apresentou distúrbios de comportamento, com alucinações e idéias persecutórias, que persistiram durante certo tempo. Obtendo remissão parcial, foram feitas várias tentativas para adaptá-lo ao trabalho naquele estabelecimento, sem qualquer resultado. Os distúrbios mentais se tornaram crônicos, com reativação periódica, pelo que foi resolvida sua remoção para o Manicômio. A observação psiquátrica elaborada a 25 de abril de 1932 revelou: incoerência na associação ideativa, de todo desorientado quanto aos dados de meio, lugar e tempo, alucinações auditivas verbais com frequentes solilóquios, atitudes de isolamento, autismo delirante.

Nada de particular quanto ao estado físico. Os exames de sangue e líquido céfalo-raquidiano foram negativos. $O$ pai era alcoolista; tem 8 irmãos sadios. Natural da Baía, viveu com os seus até a idade de 15 anos, quando então, tendo forte discussão com o pai, fugiu de sua casa. Passando pelo estado de Minas, veiu ter a S. Paulo, onde trabalhou como lavrador até a data de sua prisão, em 1926.

Diagnóstico e Conclusões - Esquizofrenia. Crime violento, com requintes de harbaria e traiçãe (a vítima dormia) sob alegação de motivo demasiado futil (discussão anterior com um amigo e companheiro de trabalho). Cerca de 1 ano após, surgiram distúrbios mentais que evoluiram para uma forma grave de esquizofrenia processual, inalterada até o presente momento (submetido ao tratamento de Von Meduna, após a vigésima crise convulsiva, não apresentou qualquer melhoria).

Observação 16 - W. H. branco, austríaco, solteiro, com 28 anos de idade, jardineiro, internado no Manicómio Judiciário em 16 de janeiro de 1932, procedente da Imigração.

Crime - Na noite de 27 de março de 1926, numa casa no distrito da Penha, W. H. vibrou em J.N. repetidas pancadas com o cano e a coronha de uma espingarda, produzindo-lhe ferimentos mortais. Em suas declarações, no inquérito c no sumário, afirmou que se levantara às 22 horas para ir à privada, e, ao voltar, deparou com J. N. no quarto em atitude agressiva, dizendo que o ia matar. Tomando então a espingarda que se achava na cabeceira de sua cama, deu forte 
pancada na fronte de J.N. que, caindo, recebeu novos golpes, pois que "tinha intenção de matá-1o".

O laudo do exame psiquiátrico (8 de maio de 1928) elaborado pelo Prof. Flamínio Fávero e Dr. José de Moraes Melo, concluiu pela irresponsabilidade do criminoso, baseado em discretos distúrbios de comportamento do réu e no caráter imotivado e violento do crime (a asserção do réu de que a vítima estava em atitude ameaçadora em contradição com o que verificou o polícia técnica de que ela dormia, foi interpretada pelos peritos como prováveis ilusões ou alucinações) . Os peritos formularam o diagnóstico de esquizofrenia.

O comportamento ulterior do paciente e o aparecimento de sintomas esquizofrênicos típicos plenamente confirmaram tal diagnóstico. Removido para o Manicômio Judiciário, a observação psiquiátrica aí elaborada, a 4 de maio de 1932, verificou: mutismo obstinado, fenómenos vários de negativismo, perversão da afetividade, atitudes catalépticas, retraimento do meio, autismo. Nada digno de nota quanto aos antecedentes $\mathrm{e}$ às condiçōes físicas. Os exames de sangue $\mathrm{e}$ líquido céfalo-raquidiano (lúes) foram negativos.

Conclusões - Trata-se de um crime sem motivação aparente, levado a efeito com grande violência por um indivíduo que, posto já um doente mental, como acertadamente concluiram os peritos que o examinaram em 1928, não apresentava, entretanto, no momento do crime, sinais psicósicos francos, tanto assim que, naquela época, se encontrava em exercício normal de sua profissão. A psicose esquizofrênica por fim se definiu tìpicamente, persistindo até o presente momento sem qualquer modificação, mau grado vários tratamentos empreendidos.

\section{MORFOLOGIA E PSICOPATOLOGIA DAS REAÇOES CRIMINAIS NO MATERIAL APRESENTADO}

Alguns fatos de grande importância se destacam ao exame acurado do material apresentado. No que diz respeito à morfologia do ato criminoso, foi constante a violència da ação agressiva de par com ausência de motivos aparentes que, quando existentes, se mostraram sempre futeis, de qualquer forma excessivamente desproporcionados aos atos por êles provocados. Houve sempre multiplicidade de golpes, com frequência, superioridade de armas, uma certa tonalidade de frieza na execução e acentuada indiferença emocional após as cênas criminosas. Algumas vezes, racionalização, noutras, nem isso, os pacientes denotando falta de compreensão das consequências dos atos que vinham de praticar. Requintes de sadismo umas vezes e, em outras, a arma homicida, atin. gindo familiares imediatos e mesmo pessôas muito amadas pelos delinquentes, dão à tragédia de sangue o colorido de morbidez que tanto afeta a opinião pública, e orientam o perito na pesquisa de motivos irracionais, profundos, de cunho patológico. Há unanimidade quanto à primacial importância das perturbações instintivo-afetivas no início da esquizofrenia. Pacientes que muitas vezes, não apresentam distúrbios grosseiros do psiquismo, pela sua atitude afetiva diante dos pais, por certa extravagância e irracionalismo no comportamento, são já portadores de formas graves de esquizofrenia ainda em sua fase precoce, enquanto muitos outros com sintomatologia florida, rica, mostrando 
grandes elaborações psicógenas, evoluem favoravelmente. Esse fato deve orientar nossa atenção para o êrro de ser formulado o diagnóstico e prognóstico da psicose com apoio tão só no aspecto sindrômico e clínico. Com Binet e Minkowski devemos nos orientar na pesquisa das perturbações principais, essenciais da enfermidade, ficando em plano secundário o aspecto sindrómico mais ou menos idêntico em todas as psicoses. Urge aproximarmo-nos o quanto possível do diagnóstico de personalidade, para isso sendo mistér a exploração profunda dos seus mecanismos básicos. Não há divergência dos autores quanto à extraordinária importância que tem o estudo do comportamento do individuo, quer no meio familiar, quer no meio social, para compreensão dos seus mecanismos psicológicos e psicopatológicos. A esta luz, o crime como reação biossocial complexa, traduz uma inadaptação momentânea ou duradoura do indivíduo ao meio social em que vive e se mostra propício, em certos casos, a esclarecer os móveis de ação do infrator das normas sociais estabelecidas. Se se nos afigura talvez exagerada, ou pelo menos estéril, do ponto de vista da profilaxia e terapêutica criminal, a asserção genérica de que o ato criminoso traduz só por si anormalidade mental, é fato indiscutível que determinados aspectos de sua morfologia convergem - sobrętudo quando a êles se associam anomalias ainda que discretas do estado mental dos seus autores - para a conclusão de que são sintomáticos de morbidez psíquica. Nesse particular insistimos sôbre a preferência para crimes de sangue, que soem se revestir de grande violência e impulsividade, traduzindo fraqueza, afrouxamento das instâncias superiores do psiquismo, nos mecanismos de "curto circuito" (Kretschmer), a ação agressiva sendo desencadeada quasi de maneira direta com supressão do arco reflexo pelo psiquismo superior. Uma certa tonalidade sádica com laivos de extravagância (caso 5), grande irracionalismo se manifestando em ações homicidas para pessôas da família (casos 8, 12, 13), são traços morfológicos de importância na formulação do diagnóstico psiquiátrico. Este é favorecido, quando o autor apresenta imediatamente antes, durante ou depois da ação criminal, os fenômenos psicopatológicos conhecidos da fase inicial dos diversos quadros mórbidos, não of erecendo qualquer dificuldade, pelo menos do ponto de vista médico-legal, quando o ato é perpretado na vigência de francos distúrbios mentais. Quando porém a perícia psiquiátrica é negativa, pelo menos no que diz respeito ao estado mental atual do delinquente, tende o perito a se orientar no estudo exaustivo da personalidade anterior, nesse particular, podendo-se aquilatar todo o alcance e valor das concepções de Bleuler, dinâmicas, quando se esforçam por completar, no estudo dos caracteres anormais, os dados da psicopatologia pròpriamente dita.

Alguns dos nossos doentes mostraram-se francas personalidades esquizóides que não transpuzeram os umbrais para a psicose franca 
sinão algum tempo após a prática do crime. Esse fato é próprio para suscitar dúvidas quanto à possibilidade de já serem êles portadores de esquizofrenia no momento do crime. $O$ caso 1 , tendo praticado o crime com caracteres de impulsividade e violência, a vitima sendo seu sobrinho e amigo, era uma personalidade esquizóide franca que só tardiamente evoluiu para uma grave esquizof renia processual. O caso 3 , com diagnóstico de esquizofrenia, forma simples, oito meses após o crime, apresentou remissão dos fenômenos psicopatológicos mais aparentes, permanecendo os traços fundamentais de esquizoidia. Em outros casos (caso 13), o diagnóstico de personalidade esquizóide anterior deu lugar, pouco tempo após o crime, ao diagnóstico de esquizofrenia grave.

Esses fatos tendem a atrair nossa atenção para a dificuldade, ou melhor para a precariedade da diferenciação, do ponto de vista clínico e psicopatológico, entre as personalidades anormais - esquizóides nesses cásos - e os estados psicóticos francos. E no que diz respeito particularmente ao problema que nos interessa - a esquizofrenia - cumpre-nos recordar o primitivo conceito de esquizofrenia latente de Bleuler só com muita dificuldade se diferenciando, se é que é possível, do conceito de esquizoidia de Kretschmer. Aliás, após os adventos dos métodos terapêuticos de choque, é fato de observação trivial a oscilação do indivíduo da esquizoidia à esquizofrenia e reversão desta para o estado psicopático anterior. Temos a impressão de não ter sido ainda estudado com o cuidado e profundeza que o assunto merece, o problema do crime das personalidades esquizóidẹs. Interessa-nos aqui apontar sobretudo que êles muito se assemelham, sinão mesmo se identificam, aos perpetrados por personalidades que, tendo ou não revelado anteriormente traços de esquizoidia, realizam crimes de morfologia com os caracteres supra-referidos e que evoluem a breve prazo para a esquizofrenia. E o que dizer então, quando, concordando com essa morfologia anormal já apontada, o perito despista certas nuances de comportamento em relação ao crime, racionalizaçôes que tendem a referir a motivos fúteis, banais, o que é motivação profunda, inconciente, já patológica, sendo isso logo sucedido pelos francos e conhecidos sinais da psicose esquizofrênica? Sem querermos apoiar de modo absoluto o ponto de vista evolutivo de Kraepelin, quando fez êle uma das pedras de toque para a creação de seus grandes sistemas nosográficos, temos que reconhecer a essencial importância deste aspecto evolutivo em nossas observações para afirmarmos com segurança terem já dependido os crimes de mecanismos psicopatológicos, numa fase precocíssima, prodrômica, preclínica da esquizofrenia. Ainda em apoio de nossas conclusões, devemos assinalar as tentativas sérias de suicídio após as cenas de sangue (casos 8 e 11) que, como opina o Prof. Heitor Carrilho ${ }^{22}$, só por si impõem a inimputabilidade criminal.

22. Carrilho, H. - Psicopatologia da paixão amorosa e seu aspecto médico-legal. Arq. Manicômio Judiciário Rio de Janeiro, $1: 33,1933$. 
Muitas vezes notamos apenas idéias de suicídio, colorindo quadros de depressão mental. Todos êsses fatos vêm em apoio da existência de um estado psicopatológico nos autores de crimes com a morfologia retro-referida que orientará o perito na pesquisa dos traços mais sutís de sua manifestação. Aqui surge um problema crucial que pode ser considerado mesmo o núcleo essencial do nosso estudo. Suspeito ou confirmado o caráter de anormalidade do réu, como aprimorar o diagnóstico diferencial com estados outros que não uma fase prodrômica da esquizofrenia? E sabido como crimes, com traços mais ou menos específicos anteriormente referidos, podem correr por conta de estados outros que a esquizof renia - a epilepsia por exemplo - devendo ser posto portanto o problema do diagnóstico difereneial que, sem dúvida, é muito delicado e difícil. Surge então a natural pergunta: é possível a formulação do diagnóstico de esquizof renia num indivíduo autor de crime de sangue, mesmo com os caracteres por nós anteriormente destacados, sem que tenha havido até o momento da ação e mesmo depois deda, qualquer dos sinais mórbidos mais ou menos característicos do período inicial da psicose? Se a resposta for afirmativa, virá a natural objeção do patologista quanto a esta situação talvez única na medicina em que o perito médico ousa diagnosticar um estado psicopatológico sem sinais clínicos evidentes desta morbidez. E, sem dúvida, nasceu daí grande parte das objeções que suscitou o conceito de esquizofrenia latente, sobretudo se, após formular tal diagnóstico, opinar o perito pela responsabilidade criminal do réu e consequentes medidas de repressão penal, ponto de vista êste estéril, sem qualquer vantagem para a psiquiatria teórica, para os interesses do réu e para a defesa social. Colocado a essa luz, afigura-se-nos justo certo descrédito que tal conceito vem tendo, não só entre os psiquiatras como dentro da justiça penal. Tal excepção a que aludimos anteriormente, quanto à formulação de um diagnóstico psiquiátrico sem sinais clínicos evidentes, ficará, a nosso vêr, justificada se nos orientarmos no sentido do diagnóstico pluridimensional (Kretschmer) e meditarmos sôbre o essencial valor da doutrina da personalidade em seus aspectos somático, temperamental e caracterológico, nas modernas concepções psiquiátricas. Certos fenômenos de transmissão hereditária, determinados traços físicos e psíquicos que caracteriłam a obra de Bleuler e Kretschmer, entre outros o importante conceito de esquizoidia etc. representam, sem dúvida, preciosos subsídios para o diagnóstico. Vezes há porém em que não são patentes tais caracteres e o diagnóstico só é feito em períodos vários depois do crime, quando a psicose esquizofrênica se caracteriza clinicamente, sendo possível à análise mental o restabelecimento do nexo causal entre o estado mental patológico e a reação criminal. A mera fenomenologia clínica, a esta luz mais estreita e profunda, se nos afigura de valor relativo, pois é sabido que, com o enriquecimento do quadro mental, tende a diminuir a perigosidade do doente, 
sob tal ponto de vista sendo muito fértil a concepção do "período médico-legal das psicoses" (Legrand du Saulle, Antheaume e Mignot). Se todos os dados porém forem negativos, afigura-se-nos de grande utilidade e interesse a criação de dispositivos legais e estabelecimentos adequados para que o réu permaneça em observação, mostrando-se aquí o ponto de vista evolutivo indispensável para uma criteriosa solução, do ponto de vista humano e médico-legal, do caso em apreço. Nesta ordem de idéias, Wilmanns ${ }^{20}$ propõe até revisão do processo, quando mais não seja para afastar do culpado e de sua família o sêlo infamante que sempre traz uma condenação, quando a psicose, irrompendo posteriormente no cárcere, aponta ao psiquiatra e à justiça o êrro cometido em fase anterior. Afigura-se-nos aquí também muito mais útil a profilaxia do que a terapêutica posterior, visto que, segundo o trabalho já citado de Hackfield ${ }^{19}$, muito diverso é o prognóstico do estado mental quando, ainda em fase precoce tais indivíduos são encaminhados para clínicas médico-psiquiátricas ou para estabelecimentos penais pròpriamente ditos.

Considerando os. casos apresentados a essa luz, vem em apoio às nossas conclusões o fato de grande parte desses pacientes, condenados a penas várias, terem, após diversos períodos de tempo, exteriorizado quadros esquizof rênicos, tendo sido por isso transferidos da Penitenciária do Estado para o Manicômio Judiciário com fins sobretudo de tratamento. Este, que teve êxito em alguns casos, o teria tido mais intensa e satisfatòriamente quiçá em todos, se tratados imediatamente após o crime, ainda na fase precocíssima da psicose. Nada mais é necessário dizer para se tornar clara a importância também sob o ponto de vista terapêutico - agora que os modernos tratamentos de choque cardiazólico e insulínico vêm se mostrando tanto mais eficientes quanto mais cêdo preconizados e levados a efeito - do despistamento da esquizofrenia nessas primeiras fases em que, ausente ainda qualquer sinal clínico pròpriamente dito, sòmente se manifestou pela ação criminal. A guisa de conclusão desejamos acentuar que, ao lado de férteis e acertadas soluções, do ponto de vista médico-legal, o êxito terapêutico há pouco assinalado vem restituir, em muitos casos, à sociedade aquele que a feriu e ofendeu mercê de mecanismos psicopatológicos ainda velados, é certo mas nem por isso menos reais e eficientes na gênese do ato criminal.

\section{CONCLUSOES}

O material por nós estudado compõe-se de 16 casos de pacientes autores de crime com determinada morfologia que por si só sugere a existência de anormalidade mental do criminoso.

$\mathrm{Na}$ morfologia dos atos criminosos destacam-se: impulsividade, ação de curto circúito (reações primitivas da personalidade), grande 
violência com traços acentuados de sadismo, a reação agressiva tendo sido sempre desencadeada sem qualquer motivação aparente ou por motivo fútil. Aquí ainda, tão evidentes traços de irracionalismo no ato criminal vêm em apoio de nossa tese, isto é, de já, por essa ocasião, serem os réus portadores de perturbação mental, sem ainda sintomatologia definida.

O estudo da personalidade prepsicótica revelou em muitos deles a existência de traços esquizóides proeminentes, por outro lado irrompendo imediatamente após o crime ou num período oscilando de 9 dias até 3 anos os sintomas fundamentais da psicose esquizof rênica. Esses fatos convergem para a natural conclusão de uma relação de causa e efeito entre o ato criminoso e um estado de morbidez psíquica.

O comportamento do autor imediatamente após o crime, na grande maioria dos casos, sugere tambem a existência de perturbação mental: indiferença emocional, por vezes fraco e franco racionalismo, absoluta ausência de compreensão das consequências do crime para si mesmo e para sua família, tentativas sérias de suicídio em alguns casos e em outros apenas idéias de autoaniquilamento colorindo estados de depressão mental etc. Uma consideração mais cuidadosa dessa situação revela nítida diferença em relação ao comportamento de outros criminosos que realizam ações agressivas mercê de motivos predominantemente racionais, nos quais a perícia psiquiátrica tambem não consegue revelar qualquer estado de morbidez mental.

O ponto central da nossa argumentação é que os pacientes por nós estudados já eram portadores de perturbação mental na época do crime, embora não houvesse ainda sintomatologia definida. Segundo as considerações anteriores, o crime representou o sinal de alarme da psicose esquizofrênica que, ainda em estado latente, evoluiu para quadros mais ou menos clássicos e conhecidos da referida psicose. Frizando o ponto de vista evolutivo de Kraepelin, o fato inconteste é que todos êsses indivíduos são atualmente portadores de graves formas de esquizof renia, a maioria delas de natureza processual.

Insistimos no presente trabalho sôbre a extraordinária importância, do ponto de vista terapêutico e médico-legal, de serem tais pacientes considerados doentes mentais na época em que delinquiram. O prognóstico será bem mais favorável, quando precocemente tratados, sobretude no ambiente adequado de um Hospital Psiquiátrico, ao contrário das medidas predominantemente punitivas ou mesmo de reeducação pelo trabalho que costumam receber nos estabelecimentos penitenciários. Além deste aspecto médico e humano, ficarão o indivíduo e sua família livres dessa nódoa altamente deshonrosa que não mais os abandonará durante toda a vida, traduzindo a injustiça de uma condenação para quem da sociedade só devera ter recebido compreensão, tratamento e proteção. 


\section{RESUMO}

Pretendem os autores, com o presente trabalho, trazer uma pequena contribuição ao importante problema do estudo do crime na fase prodrômica da esquizof renia, no chamado período médico-legal da psicose. Estudam a evolução do conceito de demência precoce de Kraepelin ao das esquizofrenias de Bleuler, detendo-se particularmente nas concepções de esquizofrenia latente e personalidade esquizóide. São referidas e discutidas as idéias de Bleuler, Kretschmer, Minkowski e Claude, em particular. Destacando a importância do diagnóstico precoce descrevem as manifestações iniciais da psicose esquizofrênica de acôrdo com os trabalhos de Kraepelin, Bleuler, Masselon, Abély, Heuyer, Berze Gruhle, Engelson e Lucena, referindo-se à importância das síndromes neuróticas como manifestação inicial - as chamadas "neuroses preesquizofrênicas" sôbre que um dos autores escreveu um trabalho anterior. Em casos referidos na literatura, crimes foram perpetrados com característicos morfológicos especiais - excessiva violência e ausência de motivação aparente em particular - seguindo-se manifestações esquizof rênicas, o que determinou o conceito de período médico-legal da esquizof renia de Antheaume e Mignot. $O$ material que apoia o presente trabalho compõe-se de 16 pacientes estudados no Manicômio Judiciário do Estado de S. Paulo, autores de graves delitos de sangue e condenados a cumprirem longa sentença na Penitenciária do Estado. Na morfologia dos atos criminosos destacaram-se: impulsividade, ação de curto-circúito (no sentido de Kretschmer), grande violência com traços de sadismo, a reação agressiva sendo desencadeada por motivos fúteis e, às mais das vezes, sem qualquer motivação aparente. A personalidade predelituosa revelou, na grande maioria, traços predominantes de esquizoidia, o crime sendo sucedido pela fenomenologia tipicamente esquizofrênica. Algumas vezes esta se manifestara logo após o crime, ora a irrupção da psicose variou de um período de 9 dias a 3 anos. A morfologia e psicopatologia no material apresentado são largamente discutidas. O estudo acurado desses casos possibilitou a conclusão fundamental de que os atos antissociais foram levados a efeito já na vigência da psicose esquizofrênica, ainda numa fase prodrômica, o crime tendo sido o sinal de alarme do grave estado mental que logo surgiria. Insistem no grande interesse, do ponto de vista terapêutico e médico-legal, da formulação de tal diagnóstico e tentam aproximar-se do problema de como poderá êle ser posto na fase ainda preclínica da psicose. Sòmente a perspectiva pluridimensional, análise e consideração minuciosas da maioria das faces do problema tornarão possível acertada conclusão diagnóstica. Quando não se tornar ela possível, propõem os autores a criação de dispositivos legais a fim de permanecerem os pacientes num período de observação e prova por tempo 
suficiente para uma precisa conclusão, o que se afigura preferível à sugestão de Wilmanns quando propõe a revisão do processo para se apagar o sêlo infamante de uma injusta condenação.

\section{SUMMARY}

This work is presented as a contribution to the problem of crime during the prodromic stage of schizophrenia, here referred to as medico-legal. As an introduction the authors discuss the basic conception of Kraepelin's dementia praecox and its subsequent developments, especially those elaborated by Bleuler, Kretschmer, Minkowski and Claude independently. They point out the early manifestations of the schizophrenic psychoses, particularly the so-called" "pre-schizophrenic neuroses" which one of the authors (D. M. U.) devoted a paper to.

Antheaume and Mignot called this stage medico-legal for a great many deal of crimes, exceedingly violent in feature and with no motivation, have cleared the way for definite schizophrenic symtoms. The clinical material considered in this paper consist of 16 patients admitted to the Court Mental Hospital, State of S. Paulo, (Manicomio Judiciario). All have been serving a long term in the State Penitentiary for heavy blood crimes. Striking features of the crimes were: 1) impulsivness; 2) short circuit action; 3) outstanding violence, sadistic in type. Moreover, precipitating factors were very irrelevant ones or there was no motivation at all. Behavior patterns previous to crime were present sometimes immediatly after conviction, sometimes at intervals from 9 days up to 3 years. Both crime dynamics and psychopathology involved are discussed.

Main conclusions to be drawn from this material is that anti-social behavior was already indicative of a schizophrenic psychosis, yet in its prodromic stage, the crime in itself being a fore-running sign. It seems to be important to bear this in mind in the legal as well as therapeutical approach of delinquency.

The authors attempt to outline the pluralistic analysis of the situation. As for the doubtful cases they suggest to refer such criminals to ward until the diagnosis may be clear, this being intended to substitute for Wilmann's suggestion concerning eventual revision of conviction.

Avenida Lacerda Franco, 1581 - S. Paulo. 